\title{
ベトナム・ニャチャン海岸における漂砂特性の 季節変動に関する検討
}

\author{
Tran Minh THANH ${ }^{1}$ • 田中 $\quad$ 仁 2 三戶部 $\quad$ 佑太 ${ }^{3} \cdot$ Nguyen Trung VIET $^{4}$ • \\ Vo Cong HOANG ${ }^{5}$ \\ 1 学生会員 東北大学大学院工学研究科土木工学専攻 \\ ( 9 980-8579 宮城県仙台市青葉区荒巻字青葉 6-6-06) \\ E-mail: thanhtranqhtl@gmail.com \\ 2 フェロー会員 東北大学大学院教授 工学研究科土木工学専攻 \\ ( 干 980-8579 宮城県仙台市青葉区荒巻字青葉 6-6-06) \\ E-mail: hitoshi.tanaka.b7@ tohoku.ac.jp \\ ${ }^{3}$ 正会員 東北大学大学院助教 工学研究科土木工学専攻 \\ ( T 980-8579 宮城県仙台市青葉区荒巻字青葉 6-6-06) \\ E-mail: yuta.mitobe.c5@tohoku.ac.jp \\ ${ }^{4}$ Thuy Loi 大学准教授 Faculty of Civil Engineering \\ (175 Tay Son, Đong Da, Hanoi, Vietnam.) \\ E-mail: nguyentrungviet@tlu.edu.vn \\ 5 学生会員 東北大学大学院工学研究科土木工学専攻 \\ ( $=980-8579$ 宮城県仙台市青葉区荒巻字青葉 6-6-06) \\ E-mail: hoangvc@tlu.edu.vn
}

\begin{abstract}
近年，局所的な海岸侵食が発生しているべトナム・ニャチャン海岸において，二台のビデオカメラによ り汀線変動を約 13 ヶ月にわたってモニターした .光の結果, 約 $650 \mathrm{~m}$ の区間において季節的な変動を示し ていることが明らかになった . 兴の変動幅は砂浜の端部で $40 \mathrm{~m}$ ほどであり，端部からの距離の増加ととも に減少していることが分かった .また，画像に記録された砕波帯幅の大小の情報から，北東モンスーン期 と乥れ以外の時期において大きく異なる波浪特性を確認することが出来た . 得られた汀線変化データから 沿岸漂砂量を推定するにあたり，このような波浪の大小に伴う移動限界水深の変化を考慮する必要がある ことから, 単純な海浜断面の仮定により, 砕波帯幅から移動限界水深を推定した . 従来の一定値とする手 法に比べ，沿岸漂砂量について有意な違いを生むことが明らかになった .
\end{abstract}

Key Words : Nha Trang Coast, Vietnam, shoreline change, longshore sediment movement, seasonal variation, video monitoring

\section{1. はじめに}

ベトナムは3,260 kmに及っ涱大な゙海岸を有している． 近年 , 公湖における堆砂, 河口部での土砂浚渫, さら には気候変動の影響などを受け, 深刻な゙海岸侵食か問題 となっている箇所が多く見られている.本研究の対象で あるニャチャン海岸はベトナム南部に位置するビーチリ ゾートであり，やはり海岸侵食か顕在化しつつある . た だし，途上国においては我力国のように十分な海浜測量 データ，波浪データか存在するわけではなく，このこと が゙トナムでの漂砂環境に関する定量的な検討を困難と している。

この樣な背景から，これまでのベトナムにおける海浜 変形を検討するためのアプローチとしては, Landsatや
Google Earthなどの衛星画像を用いた検討 (例えば,宇多 $ら^{1)}$, 宇多ら ${ }^{2)}$, Thuyら $ら^{3)}$, Nguyen et al. ${ }^{4)}$ ，田中ら ${ }^{5)}$ ) が多 くなされている .

本研究においては, ニャチャン海岸においてビデオカ メラによる汀線変動の継続的なモニタリングを行った . また , この観測結果をもとに，モンスーン期・非モンス 一ン期の波浪特性の相違を考慮した移動限界水深の推定， および沿岸漂砂量の推定を行った .なお，前報()におい てはニャチャン海岸北端部に設置された一台のカメラか ら得られた $300 \mathrm{~m}$ ほどの狭域の汀線変動を検討している のに対して , 本論文においては二台のカメラによる画像 を用いることにより，沿岸方向に $650 \mathrm{~m} に$ 及污広範囲に おける汀線を扱っている．また，画像から得られる砕波 帯幅より移動限界水深の推定を行っている. 


\section{2. 研究対象および使用データ}

ニャチャン海岸はホーチミン市から北東に約 $300 \mathrm{~km}$ に位置する長さ約 $4.3 \mathrm{~km}$ の砂浜海岸である (図-1) . 本研 究においては, このうち侵食傾向か湿在化している北部 $650 \mathrm{~m}$ 程度の範囲を対象としている (図-2) . ベトナム科 学技術省 (Ministry of Science and Technology, MOST) お よびフランス開発研究所 (Institute of Research and Development ,IRD) の共同研究プロジェクトにより2013年5 月に2台のカメラによるビデオモニタリングシステムが 図-1に示した青丸印の箇所に設置された . 弚の後, 現

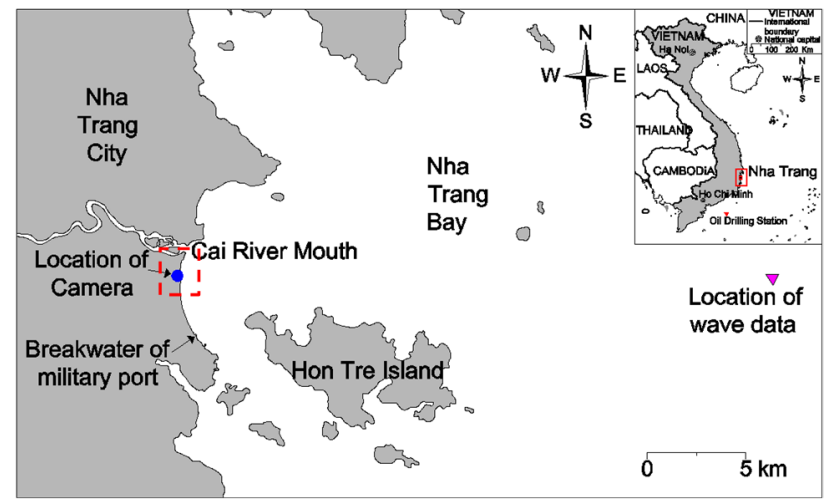

图-1 ニャチャン海岸の位置

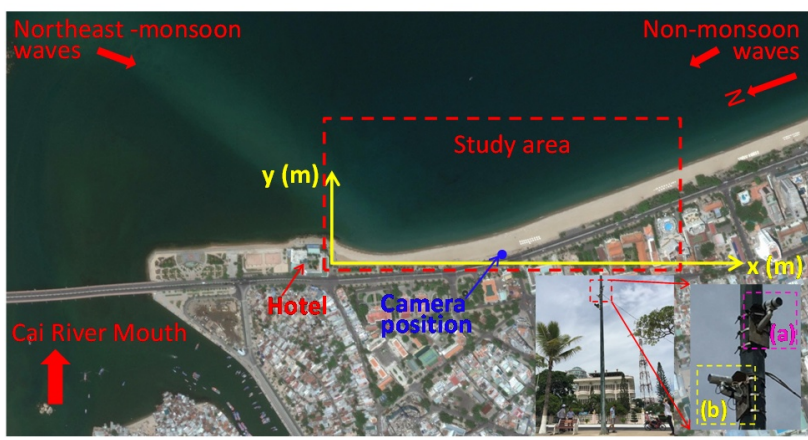

図-2 調査海浜の詳細

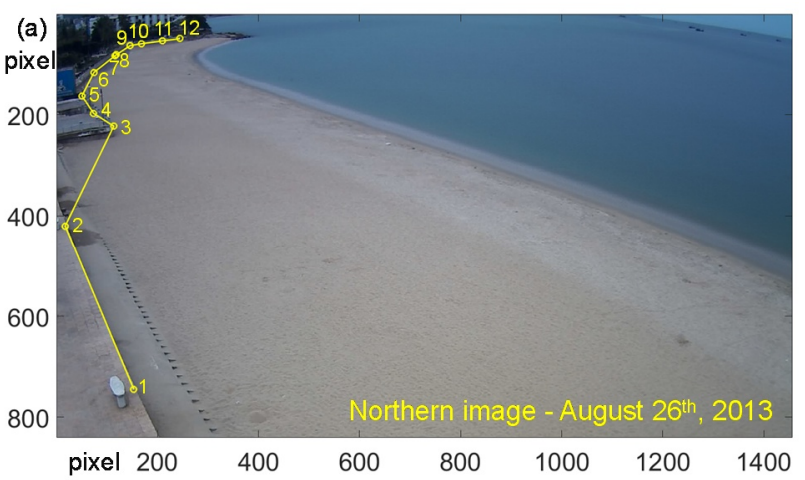

(a) 北向きカメラによる画像
在まで連続的に映像を取得し，海浜変形過程をモニター している。

撮影された斜め画像を射影変換することにより平面 画像に変換し, 汀線位置の変動を得ることが出来る.こ のうち1台は砂浜北端部を観察するために北向きに，もう 1台は南向きに設置されている .ビデオカメラを用いたモ ニタリングにより高頻度かつ長期間の撮影画像から詳細 に海浜変形過程を捉えることができる . 本研究て使用す るビデオカメラでは午前 6 時から午後 5 時 15 分までの間毎 秒1枚の間融て撮影を行っており，本研究では2013年5月 26日から2014年7月25日までのおよ光1年間の画像を収集 した .これらの画像について15分間毎に撮影された画像 の平均を取った時間平均画像を作成した . 潮位変化によ る汀線変動の影響を無視するため, 最も近くにある観測 所における潮位デー夕に基ついて , 潮位力平均潮位と一 致する時刻の画像のみを対象として解析を行った .これ らの画像処理の手法は前報のと同一である .

\section{3. 結果と考察}

（1）画像解析結果の一例

図-3には南北方向を向いた二台のカメラから得られた 平均画像の一例を示している.図-3(b)の南側を撮影した 画像においては比較的直線的な゙汀線力続くのに対して， 図-3(a)の北側を撮影した画像においては汀線が徐々に 曲線を描き，弚の端部は図-2に示すホテルの護岸に接し ている。

図-3の樣な画像に射影変換を施すにあたり，図-3に見 られる護岸に沿って選択した , 標高が一定の12個の地上 基準点をもとに行った .

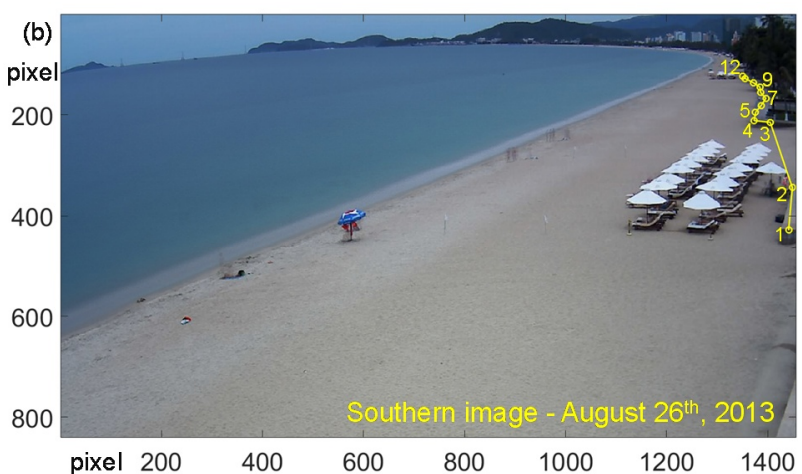

(b) 南向きカメラによる画像

図-3 ビデオカメラから得られた平均画像の一例 


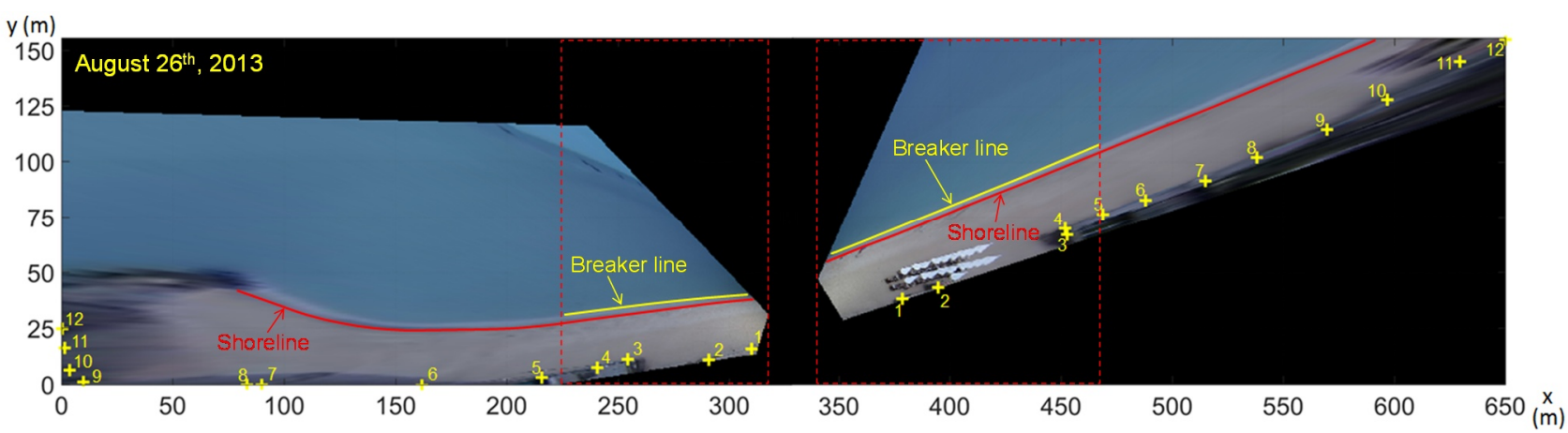

(a) 2013 年 8 月 26 日 (非モンスーン期)

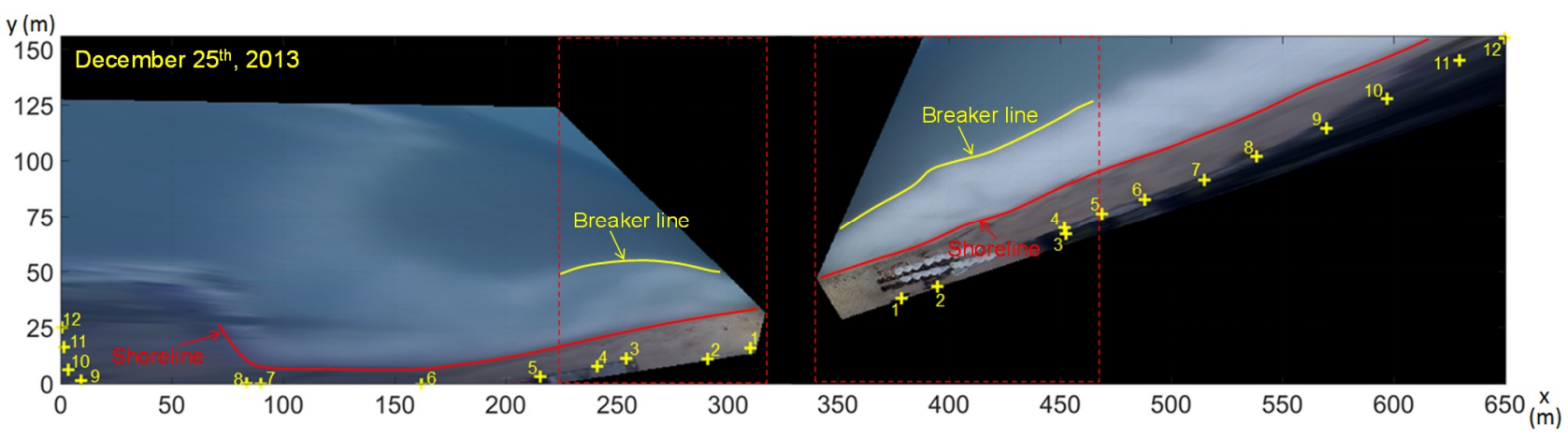

(b) 2013 年 12 月 25 日 (モンスーン期)

図-4 射影变換後の画像の一例

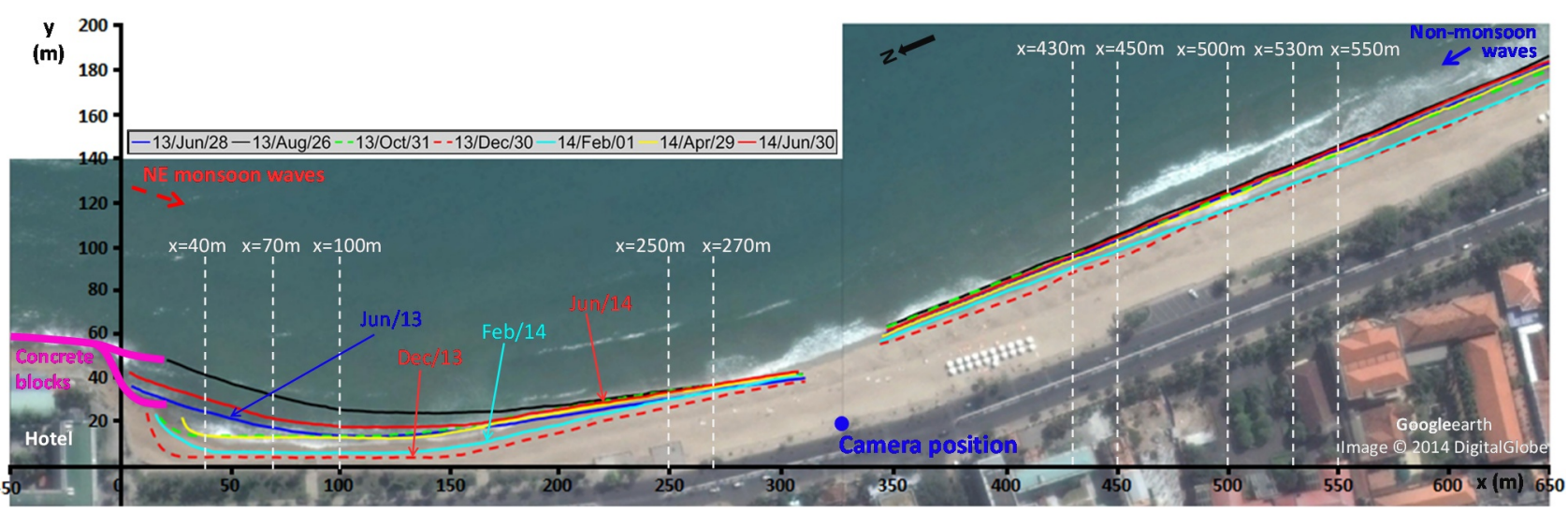

図-5＼cjkstart射影変換後の画像から得られる汀線変化

この樣な射影変換により得られた画像の一例を図-4に 示した ベトナムにおいては10月から3月にかけての北東 モンスーン期と4月から8月にかけての南西モンスーン期 に分類される . 図-1に示すべトナムの地形特性から , 北 東モンスーン期には高波浪が来襲するが, 光れ以外の季 節の波浪は微弱である.特に, 図-1に示す樣に二ャチャ ン海岸は南からの波に対してホンチャ島の遮蔽域に位置 している .このため, 波浪の大きさか㳵節により大きく 変化する .

図-4に示した画像はこのような゙波浪特性を反映したも のになっている . まず, 図-4(b)においては, 特に南向き カメラにより白い砕波帯力明瞭に記録されているのに対 して , 図-4(a)ではこれが全く見られない . また , 波向き
の相違を反映して , 北東モンスーン期の図-4(b)の $100 \mathrm{~m}$ $\leqq x \leqq 200 \mathrm{~m}$ の間においては汀線力護岸まで後退してい るのに対して , 図-4(a)においては汀線の前進が見られる . この時期に , 波浪は南から入射し , さらにホンチャ島に よる遮蔽の影響があるものの, 汀線に対してきつい角度 で入射するために, 北東モンスーン期に生じた侵食域を 回復させるほどの沿岸漂砂か生じていることか分かる .

同樣な゙汀線抽出を行うことにより，図-5の樣な゙汀線変 化図を得ることが出来る . 後述の樣に ,この樣に得られ た汀線の変化速度を空間積分することにより, 砂の連続 式から沿岸漂砂量を推定することか可能である .ただし， この際の問題点は底質の移動限界水深 $D_{c}$ の推定である . 通常は実測断面あるいは代表波浪から一定の $D_{c}$ 値を決 
定してこれを用いるが , ニャチャン海岸においては図-4 からも明らかなように波浪力微弱な時期には，このよう な一定の $D_{c}$ 值を用いた時に漂砂量を過大評価すること になる・ただし, 詳細な深浅測量データや波浪データが 存在しないことから, 以下では画像から読み取ることの 出来る砕波帯幅を用いてD値の推定を行った。

\section{（2）汀線と砕波帯幅の変動}

図-6に見られる樣に，二ャチャン海岸における汀線位 置y $y_{s}$ は冬季の後退, 弚の後の前進が周期的に繰り返され ており, 明確な季節変動力認㕫られ . 冬季には北東か らのモンスーン波浪が入射する. 冬季の汀線後退はこの 波に対応している.

一方，図-7には，図-4に例示した砕波帯幅の位置灭の 変化を示した 砕波帯幅は北東モンスーン期の10月から 3 月にかけて増加しており，弚の増加時期は図-6の汀線後 退に対応している.一方, 砕波帯幅力急激に減少した2 月,3月以降, 汀線の回復が見られる.図-4に示した赤破 線の区間 $(230 \mathrm{~m} \leqq x \leqq 290 \mathrm{~m}, 360 \mathrm{~m} \leqq x \leqq 470 \mathrm{~m})$ におい て砕波帯幅を平均した結果か泪-8である.さらに，モン スーン期 , 非モンスーン期について砕波帯幅の平均値を

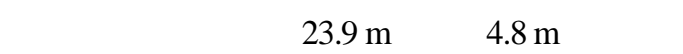

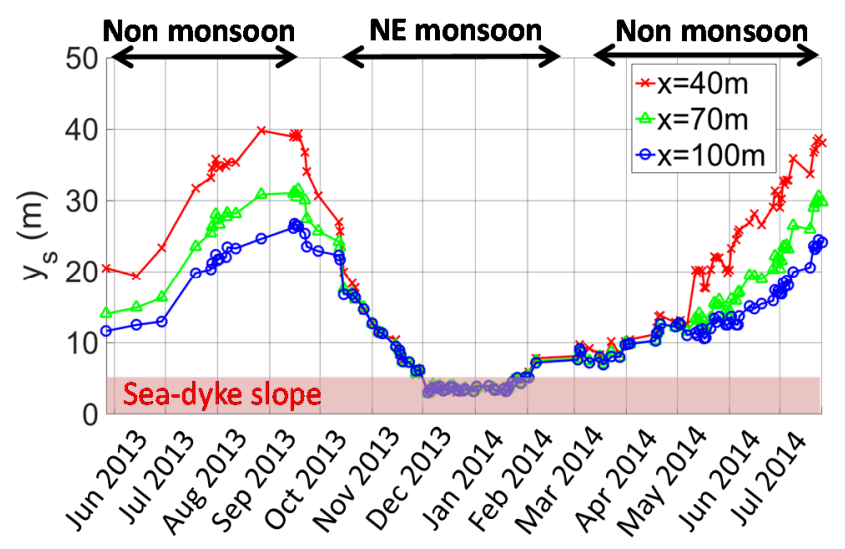

（3）モンスーン特性を考慮した移動限界水深の推定

移動佷界水深 $D c$ を推定するにあたり，十分な実測值が あれば, 海浜断面積と汀線変化量の間の比例定数として 求めることが出来る7)。一方, このような実測值がい 場合には , Hallermeier ${ }^{8)}$ や, 次のBirkemeier ${ }^{9} の$ 式により求 めることが多い .

$$
D_{C}=1.75 H_{S}-57.9 \frac{H_{S}^{2}}{g T_{S}^{2}}
$$

ここで， $H_{S} ， T_{S}$ : 有義波波高，周期である．一方，宇多 ${ }^{7}$ は次式のように $D_{c}$ 砕波波高 $H_{b}$ と相関することを報告 している。

$$
D_{C}=a H_{b}
$$

ここで，砕波指標として簡便な次式を使用する．

$$
H_{b}=\gamma h_{b}
$$

ここで, $h_{b}$ : 砕波水深, $\gamma$ : 定数である.さらに簡単のた めに, 海浜勾配 $\tan \beta=$ 一定すれば，砕波帯幅 $W$ と砕波水 深 $h_{b}$ の間に次式が成り立つ.

$$
\tan \beta=\frac{h_{b}}{W}
$$

図-6 汀線の変動
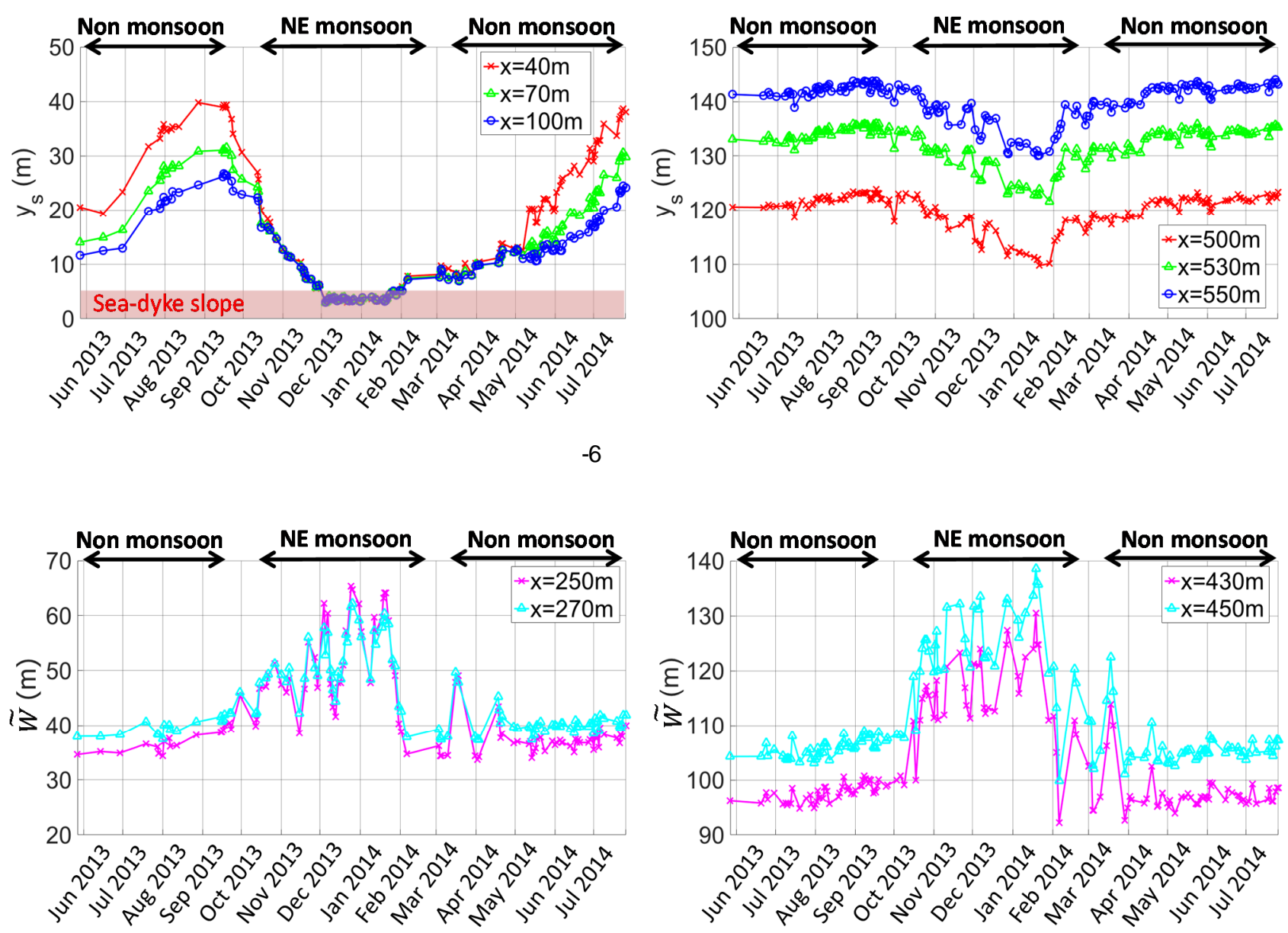

図-7 砕波位置の変動 


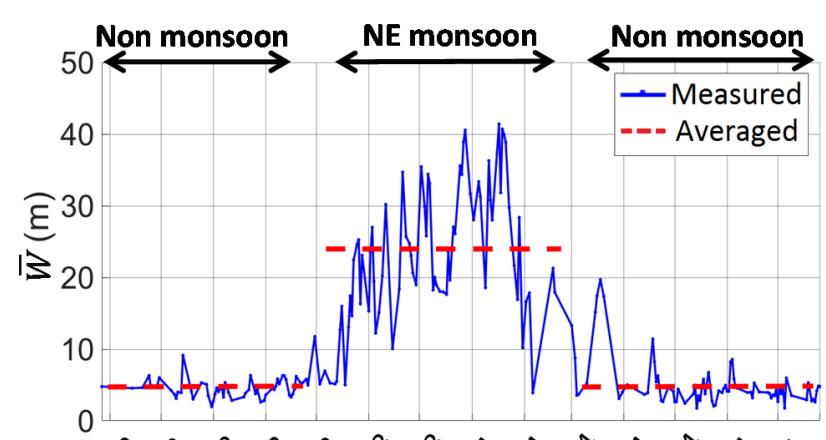

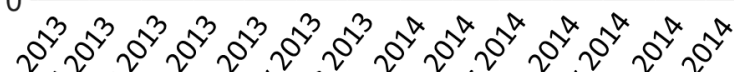

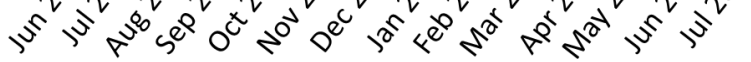

図-8 平均の砕波帯幅

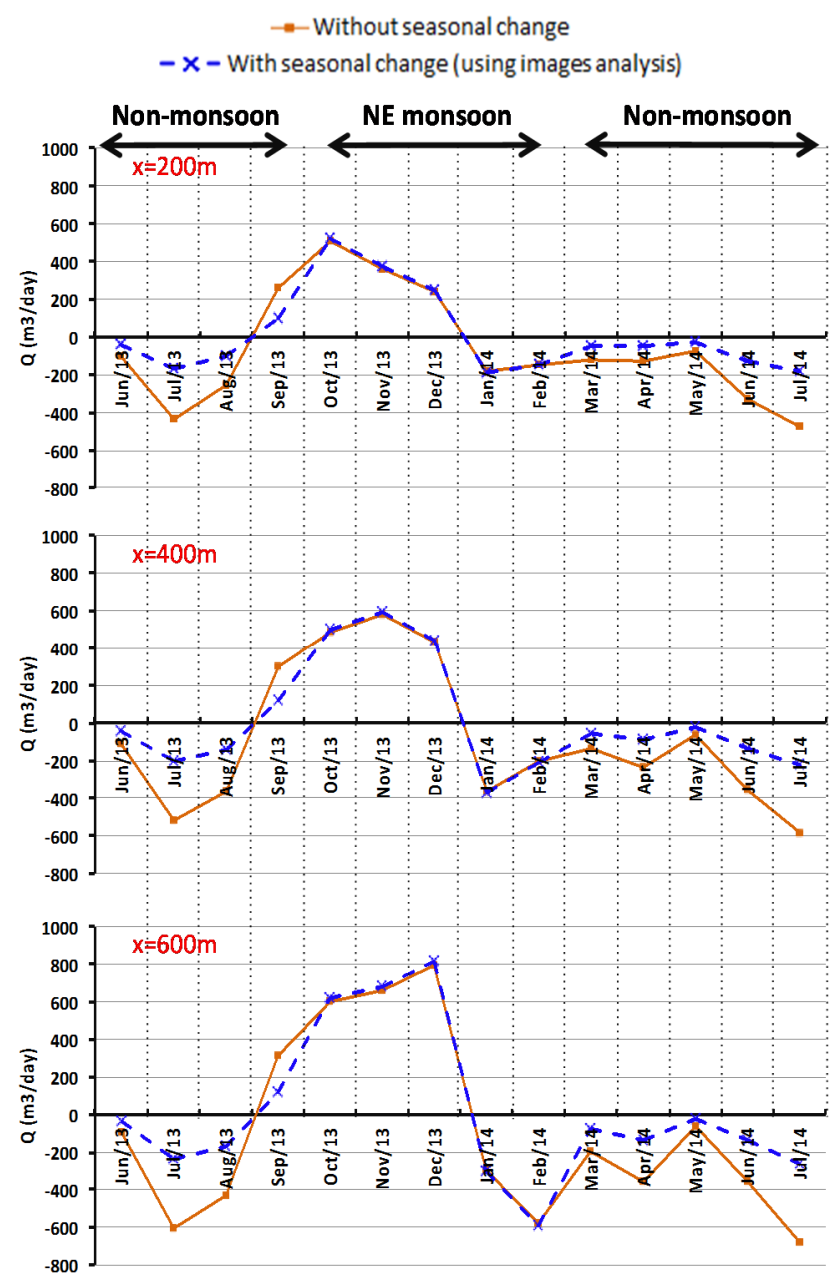

図-9 推定された沿岸漂砂量

以上の式(2)，式(3)，式(4)より， $D_{c}$ の算定式として次式 カ得られる.

$$
D_{C}=a \gamma \tan \beta W
$$

これより，北東モンスーン期の移動限界水深 $D_{c(N E)}$ と光れ 以外の季節の移動限界水深 $D_{c(N o n)}$ の比は次式で与えられ る。

$$
\frac{D_{c(N E)}}{D_{c(N o n)}}=\frac{\bar{W}_{N E}}{\bar{W}_{N o n}}
$$

以上より，砕波帯幅Wから移動限界水深を推定すること か出来る。

図-8において , 北東モンスーン期および非モンスーン 期について赤い破線で示した平均值を用いることとす る.この砕波帯幅より式(6)の比か定まる .ここで, 北東 モンスーン期については別途行われたSWANによる推定 波浪に対してモンスーン期間内の $0.137 \%$ 超過確率を有

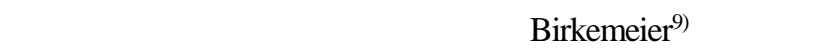

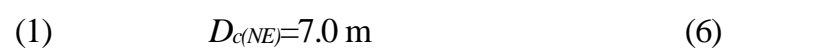
モンスーン期の值は $D_{c(N o n)}=1.4 \mathrm{~m}$ となった .

\section{(4) 漂砂量の推定}

図-2の砂浜左端に存在するホテルは消波護岸により防 護され，ホテル敷地が吕状にせり出し, 海浜に対して突 堤に類似した機能を有している.このため，ここでの沿 岸漂砂をゼロとすれば , 任意の箇所での沿岸漂砂は，

$$
Q(x)=-\left(D_{C}+D_{B}\right) \int_{0}^{x} \frac{\Delta y_{s}}{\Delta t} d x
$$

から求めることか出来る .ここで, $D_{B}:$ バ一ム高さ , 汀線 位置の時間変化 $\Delta y_{s} / \Delta t$ につては図-6のビデオモニタ 一結果を使用した。通常， $D_{c}$ はある超過確率を有する波 浪条件から，既存の経験式を用いて推定することが出来 る.しかし, ニャチャン海岸においては波浪か明暸な季 節変動を有することから，年間を通じて一定の $D_{c}$ 值を使 用することは適切ではない，乥こで，上記ビデオ画像か ら推定值をモンスーン期・非モンスーン期に分けて使用 し，一定值とした推定結果との比較を行った．

結果を図-9に示した . 図-9によれば，モンスーン期に 正值 (南向き) の漂砂か生じており, 図-6の汀線後退が 生じることか明らかになった . また, 静穏期の負の漂砂 の時期には $D_{c}=$ constとする方法との間で有意な差違か栍 じている。

\section{4. おわりに}

移動限界水深の季節変動を加味して, ベトナム・ニャ チャン海岸における沿岸漂砂量の季節変動を推定した . 一定の移動限界水深値を使う場合と異なり，北東モンス ーン時の南下漂砂に比ベ, 非モンスーン時の北上漂砂が 過小であるとの結果を得ることから net の沿岸漂砂量に ついて議論を行う際にきわめて重要な物理過程であるこ とが判明した . 将来 , ワンラインモデルなどのシミュレ ーションを行う際，この樣な特性を反映させることが必 


\section{要である .}

\section{参考文献}

1) 宇多高明,野志保仁,小林昭男,芹沢真澄, 宮原志帆, 伊達文美: Vietnam の Vung Tau 近傍の Co May River 河 口部における地形変動, 土木学会論文集 B3 (海洋開 発)，Vol.71, No.2, pp.I_766-I_771, 2015.

2) 宇多高明, 小林昭男, 芹沢真澄, 伊達文美, 野志保仁, 宮原志帆: Vietnam の Vung Tau 近郊での河口砂州伸長 と rhythmic pattern の海浜形成, 土木学会論文集 B3(海 洋開発)，Vol.71(2), pp.I_760-I_765, 2015.

3) Mai Thi Thu Thuy, 長塚信二, 西畑 剛, 武若 聡, 三村信男，安原一哉，Do Minh Duc: ベトナム北部八 イハウ海岸の大規模侵食の経過と光の分析, 土木学 会論文集 B2 (海岸工学), 第 68 巻, pp.1441-1445, 2012.

4) Nguyen, T. L., Tran, T. T., Nguyen, H. S., Than, V. V. and Lacroix, Y.: Estimation of shoreline changes of the Cai River estuary in Vietnam, Proceedings of Vietnam-Japan Workshop on Estuaries, Coasts and Rivers, 2015.
5) 田中 仁, Vo Cong Hoang ,Nguyen Trung Viet ,Dinh Van Duy: ベトナム中部クアダイ海岸に形成された河口テ ラスと大規模海岸侵食との関連, 土木学会論文集 B1 (水工学) , Vol.72, No.4, pp.I_361-I_366, 2016.

6) Tran Minh Thanh , 田中 仁 , Nguyen Trung Viet ,三戶 部佑太 ,Vo Cong Hoang: 冬季モンスーン波浪の卓越を 考慮したニャチャン海岸における沿岸漂砂量評価, 土木学会論文集 B2 (海岸工学), Vol.71, No.2, pp.I_1681-I_1686, 2015.

7) 宇多高明: 日本の海岸侵食, 山海堂, 442p, 1997.

8) Hallermeier, R. J. : A profile zonation for seasonal sand beaches from wave climate, Coastal Engineering, Vol.4, pp.253-277, 1981 .

9) Birkemeier, W. A. : Field data on seaward limit of profile change, Journal of Waterway, Port, Coastal and Ocean Engineering, Vol.111(3), pp.598-602, 1985.

(2016.2.4 受付)

\section{STUDY ON SEASONAL VARIATION OF SEDIMENT MOVEMENT ON NHA TRANG COAST, VIETNAM}

\section{Tran Minh THANH, Hitoshi TANAKA, Yuta MITOBE, Nguyen Trung VIET and Vo Cong HOANG}

Each year, there have been many storms and strong monsoon waves that caused significant change of coastal morphology in the coastal zones of Vietnam. In the central of Vietnam, Nha Trang Coast also has a severe shoreline erosion problem, especially beach in the northern area of southern Nha Trang Bay disappears in several months every year. In this study, seasonal variation of morphology in this area is investigated. The detailed process of morphological change is presented based on analysis of fifteen-minute time-averaged images from northern and southern camera of video monitoring system. In addition, on the basis of the camera images analysis for surf zone characteristics, depth of closure is identified in consideration of different wave conditions between the northeast monsoon season and the non-monsoon season; hence the estimation of closure depth based on width of surf zone is also proposed in this analysis. Following that, longshore sediment transport rate for corresponded seasons is computed. 